\title{
EFFECTS OF CROP DENSITY ON FODDER YIELD IN CABBAGE PRODUCTION ${ }^{1}$
}

\author{
Đ. Moravčević, V. Bjelić, S. Vučković2
}

Abstract: The two-year trials (2001-2002) with cabbage were performed at Vinča in the Belgrade region. The crop densities (five densities) ranged from 20,408 to 47,620 plants ha ${ }^{-1}$. The cabbage fodder yield was high (ranging from 21.40 to $28.91 \mathrm{t} \mathrm{ha}^{-1}$ ). Leaves and stems are used as fodder. The best results were obtained in the moderate crop densities (approximately 35,000 plants ha ${ }^{-1}$ ). Late autumn cabbage was studied.

Key words: cabbage, crop density, fodder, yield.

\section{Introduction}

Cabbage is a vegetable grown for its heads. When heads are harvested, stems and leaves (crop residues) remain in the field. These residues (stems and leaves) are usually ploughed down and used as green manure. They can also be used as animal feed (fodder). When fresh, they contain $4.2-5.8 \%$ of carbon hydrates, $1.6-1.9 \%$ of proteins, $0.8-1.3 \%$ of cellulose, $0.12-0.18 \%$ of plant oils and $0.7-1.2 \%$ of mineral matters. The participation of vitamin $\mathrm{C}$, carotene and vitamin B1 amounts to $38 \mathrm{mg} \%, 0.062 \mathrm{mg} \%$ and 0.05 $\mathrm{mg} \%$, respectively. Concerning mineral matters, they mostly contain potassium, calcium and sulphur (Makarevič, 1998).

Stems and leaves (fodder) constitute $35-42 \%$ of the total plant mass (Ghanti et al., 1982). They can be used in the fresh, dry or silage form. If animals are fed with greater fodder amounts, milk and meat can have cabbage-like odour, and bloat can occur in livestock.

Crop densities in the case of cabbage depend on several factors. The first among them is the variety (hybrid). In fact, crop density depends on variety vigor. Early varieties are the least vigorous ones. Their growth habit is rather limited enabling production in higher crop densities $\left(40,000-70,000\right.$ plants $^{-1} a^{-1}$. Late varieties, which are as a rule rather vigorous, are grown in lower crop densities (25,000-40,000 plants ha $\left.{ }^{-1}\right)$. Different varieties should not be grown in the same crop.

Soil is the second factor. Rich and poor soils should be distinguished. A greater number of plants may grow on richer than on more poor soils. The differences may be lessened if large fertilizer quantities are applied on poor soils.

Soil water regime is also very important for crop density. Under dry conditions cabbage should be grown in lower crop densities enabling its root system to exploit a larger soil volume in order to absorb the necessary moisture. Crop densities may be increased when possibilities for plant irrigation exist.

Different data pertaining to crop densities in cabbage production have been so far cited in the literature. Crop densities most frequently stressed as highly suitable range from 25,000 to 40,000 plants per hectare. These data pertain to late cabbage varieties.

According to Russian authors (Avakimov, 1988; Makarevič, 1998) the most favourable crop density for late cabbage varieties amounts to approximately 35,000 plants $\mathrm{ha}^{-1}$. This density is obtained if cabbage is transplanted according to the $60 \times 40-50 \mathrm{~cm}$ system.

For growing conditions in Hungary Szalva (1982) recommends a crop density of approximately 40,000 plants $\mathrm{ha}^{-1}$. Similar data are also cited by other authors. Optimal crop densities for late cabbage varieties have not been studied in our country (Serbia) so far, so that this is the first attempt to obtain certain results in this respect.

1 Original scientifis paper - Originalni naučni rad

2 BsC Đorđe Moravčević, Assistant, PhD Vukašin Bjelić, Professor, PhD Savo Vučković, Professor, Faculty of Agriculture, University of Belgrade, Belgrade-Zemun 


\section{Material and methods}

The two-year field trials with a cabbage variety Srpski melez 4 of the local origin were carried out on forest brown soil in the vicinity of Belgrade (Vinča) in 2001 and 2002. The growing season of this variety ranges from 130 to 140 days. It is used as a fresh or a processed vegetable.

Transplants (seedlings) were grown in open beds. Five grams of seeds were sown per $\mathrm{m}^{2}$ in June $\left(9^{\text {th }}\right.$ and $\left.7^{\text {th }}\right)$. Cabbage was transplanted in the 5-6-leaf stage. The row spacing was constant $(70 \mathrm{~cm})$, while plant spacings in the row varied $(30-70 \mathrm{~cm})$. In such a way the following densities were obtained: 20,$408 ; 23,810$; 28,$570 ; 35,715$ and 47,620 plants ha $^{-1}$.

The four-replicate trials were set up according to the randomised complete-block design. The elementary plot size amounted to $12 \mathrm{~m}^{2}(5 \times 2.8 \mathrm{~m})$. Cabbage was regularly watered, hoed and protected against diseases and pests.

Harvest of heads was done in November $\left(7^{\text {th }}\right.$ and $\left.5^{\text {th }}\right)$. Harvested plants were pulled out and divided into stems and leaves, which were used to determine the fodder yield $\left(\mathrm{t} \mathrm{ha}^{-1}\right)$. Obtained results were processed by the analysis of variance.

Weather conditions

The year of 2002 had more favourable conditions than the year of 2001 (Table 1). It is attributed to precipitation with a very uniform distribution. The monthly precipitation varied from 50 to $107 \mathrm{~mm}$. Although rainfall was abundant in 2001, the distribution was uneven. As much as $369 \mathrm{~mm}$ of rain fell in June and September, which was $80 \%$ of the total precipitation

Table 1. Mean monthly temperature and monthly sums precipitation during the period of investigation

\begin{tabular}{|c|c|c|c|c|}
\hline \multirow{2}{*}{ Months } & \multicolumn{2}{|c|}{ Temp. $\left({ }^{\circ} \mathrm{C}\right)$} & \multicolumn{2}{c|}{ Precipitation $(\mathrm{mm})$} \\
\cline { 2 - 5 } & 2001. & 2002. & 2001. & 2002. \\
\hline VI & 19.0 & 22.4 & 186 & 80 \\
\hline VII & 23.2 & 24.7 & 21 & 62 \\
\hline VIII & 24.3 & 22.8 & 55 & 107 \\
\hline IX & 17.2 & 17.9 & 183 & 50 \\
\hline X & 15.9 & 13.9 & 16 & 30 \\
\hline Average/Sum & 19.9 & 20.3 & 461 & 379 \\
\hline
\end{tabular}

for the experimental period. On the other hand, there almost was no rain in July and October (21 and $16 \mathrm{~mm}$, respectively). The temperatures were favourable for cabbage. The year of 2002 had somewhat more favourable temperatures than the year of 2001 (they were more consistent).

Results and discussion

The average stem yield amounted to $3.49 \mathrm{t} \mathrm{ha}^{-1}$ (Table 2). Yields obtained in 2002 were higher by $0.22 \mathrm{t} \mathrm{ha}^{-1}$ than yields achieved in 2001. The highest yields $\left(3.68\right.$ and $\left.4.18 \mathrm{t} \mathrm{ha}^{-1}\right)$ were achieved in the highest crop densities $(35,715$ and 47,620 plants

Table 2. Stem yield

\begin{tabular}{|c|c|c|c|}
\hline \multirow{3}{*}{$\begin{array}{l}\text { Crop density } \\
\left(\text { plant ha }{ }^{-1}\right)\end{array}$} & \multicolumn{2}{|c|}{ Yield $\left(\mathrm{t} \mathrm{ha}^{-1}\right)$} & \multirow{3}{*}{ Average } \\
\hline & \multicolumn{2}{|c|}{ Years } & \\
\hline & 2001. & 2002. & \\
\hline 20,408 & 3.07 & 3.16 & 3.12 \\
\hline 23,810 & 3.13 & 3.38 & 3.25 \\
\hline 28,570 & 3.11 & 3.34 & 3.22 \\
\hline 35,715 & 3.52 & 3.84 & 3.68 \\
\hline 5. $\quad 47,620$ & 4.09 & 4.28 & 4.18 \\
\hline Average & 3.38 & 3.60 & 3.49 \\
\hline $\begin{array}{ll}\text { LSD } & 0.05 \\
& 0.01\end{array}$ & $\begin{array}{l}0.39 \\
0.64\end{array}$ & $\begin{array}{l}0.42 \\
0.76\end{array}$ & $\begin{array}{l}- \\
-\end{array}$ \\
\hline
\end{tabular}


$\mathrm{ha}^{-1}$, respectively), while remaining yields significantly lagged behind by 0.46 to $1.06 \mathrm{t} \mathrm{ha}^{-1}$. According to Rahman and Haque (1982) the stem yield amounted to $4.76 \mathrm{t} \mathrm{ha}^{-1}$. These authors studied four densities (24,750-43,230 plants ha $\left.^{-1}\right)$ and determined that the highest yields were obtained in the moderate crop densities (approximately 33,000 plants $\mathrm{ha}^{-1}$ ). On the contrary, Srinivas (1982) established that higher crop densities resulted in higher yields. This author recommended the crop density of 45,000 plants ha $\mathrm{a}^{-1}$. The stem yield in this density was $6 \mathrm{tha}^{-1}$.

The average leaf yield was $20.90 \mathrm{t} \mathrm{ha}^{-1}$ (Table 3). The leaf yield was higher in 2002 and the difference amounted to $1.48 \mathrm{tha}^{-1}$. A higher yield was achieved in higher crop densities. Hence, the highest leaf yield of $24.73 \mathrm{tha}^{-1}$ was obtained in the highest crop density $\left(47,620\right.$ plants ha $\left.^{-1}\right)$. This yield was followed by leaf yield of $22.79 \mathrm{tha}^{-1}$

Table 3. Leaf yield

Tabela 3. Prinos lista

\begin{tabular}{|c|c|c|c|c|}
\hline \\
\hline \multirow{3}{*}{\multicolumn{2}{|c|}{$\begin{array}{l}\text { Crop density } \\
\left(\text { plant ha }{ }^{-1}\right)\end{array}$}} & \multirow{2}{*}{\multicolumn{2}{|c|}{$\frac{\text { Yield }\left(\mathrm{t} \mathrm{ha}^{-1}\right)}{\text { Years }}$}} & \multirow{3}{*}{ Average } \\
\hline & & & & \\
\hline & & 2001. & 2002. & \\
\hline 1. & & 17.98 & 18.59 & 18.28 \\
\hline 2. 23 & & 18.33 & 20.23 & 19.28 \\
\hline 3. & & 18.19 & 20.67 & 19.43 \\
\hline 4. 35 & & 21.97 & 23.61 & 22.79 \\
\hline 5. & & 24.35 & 25.11 & 24.73 \\
\hline & & 20.16 & 21.64 & 20.90 \\
\hline LSD & $\begin{array}{l}0.05 \\
0.01\end{array}$ & $\begin{array}{l}3.52 \\
5.19\end{array}$ & $\begin{array}{l}2.89 \\
4.93\end{array}$ & $\begin{array}{l}- \\
-\end{array}$ \\
\hline
\end{tabular}

obtained in the second highest crop density $\left(35.715 \mathrm{t} \mathrm{ha}^{-1}\right)$. The lagging behind the highest yield amounted only to $1.94 \mathrm{t} \mathrm{ha}^{-1}$. All other yields were lower and ranged from 18.28 to $19.43 \mathrm{t} \mathrm{ha}^{-1}$. Bradshaw (1984) obtained similar results in studies with six crop densities $\left(23,700-46,450\right.$ plants ha $\left.{ }^{-1}\right)$. The average leaf yield in these studies amounted to $26.37 \mathrm{t} \mathrm{ha}^{-1}$. Kang et al. (1988) in their trial with three crop densities not differing from one another much $\left(27,740-32,415\right.$ plants $^{-1} \mathrm{a}^{-1}$ obtained uniform leaf yields $\left(20.47-22.19 \mathrm{t} \mathrm{ha}^{-1}\right)$.

The fodder yield amounted to $24.39 \mathrm{t} \mathrm{ha}^{-1}$ on the average (Table 4). This yield was higher by $1.70 \mathrm{t}$ $\mathrm{ha}^{-1}$ in 2002 . The highest fodder yields of 26.47 and $28.91 \mathrm{t} \mathrm{ha}^{-1}$ were obtained with crop densities of 35,715 and 47,620 plants ha ${ }^{-1}$, respectively. These

Table 4. Total yield of fodder

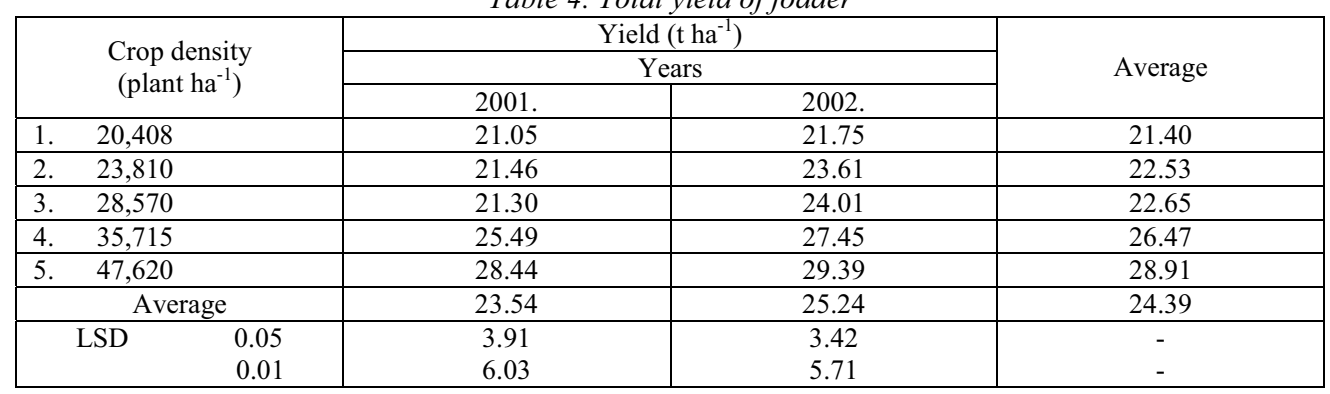

yields were significantly higher than other obtained yields whose lagging amounted to 3.82 and $7.51 \mathrm{t}$ ha 1. Stoffela and Fleming (1990) state that fodder yield could be up to $36 \mathrm{t} \mathrm{ha}^{-1}$. The highest yields were obtained with moderate high crop densities (approximately 33,000 plants ha ${ }^{-1}$ ). Szalva (1982) pointed out that the fodder yield did not exceed $22.37 \mathrm{t} \mathrm{ha}^{-1}$, but these results were related to the production of early maturity cabbage. McLaurin et al. (1991) treated only leaves as fodder. These authors obtained leaf (fodder) yields of 23.04 to $28.41 \mathrm{tha}^{-1}$. The highest yield was obtained in the highest crop density $\left(42,310\right.$ plants ha $\left.{ }^{-1}\right)$. 


\title{
Conclusion
}

The obtained results show that cabbage is a good source of fodder. Fodder consists of stems and leaves. The average fodder yield amounted to $24.39 \mathrm{t} \mathrm{ha}^{-1}$. The higher crop densities resulted in higher yields, and vice versa. Yields were higher in 2002 due to a more even precipitation distribution. The optimum crop density for the studied cabbage (the variety Srpski melez 4) amounted to approximately 35,000 plants ha ${ }^{-1}$.

\section{UTICAJ GUSTINE USEVA NA PRINOS KRME U PROIZVODNJI KUPUSA}

\author{
Đ. Moravčević, V. Bjelić, S. Vučković
}

\section{Rezime}

Kupus je proučavan u poljskim ogledima. To je rađeno dve godine (2001. i 2002). Ogledi su izvođeni u rejonu Beograda (Vinča). Gustina useva se kretala od 20.408 do 47.620 biljaka ha $^{-1}$ (5 gustina). Proučavan je kasni kupus.

Prinos krme je u proseku dostigao 24,39 $\mathrm{t} \mathrm{ha}^{-1}$. Kupus se bolje pokazao u gušćim usevima. To se najviše odnosi na useve čija je gustina iznosila 35.715 i 47.620 biljaka ha $^{-1}$. U tim gustinama kupus je u proseku davao 26,47 i 28,91 t ha ${ }^{-1}$ krme. Razlika iznosi samo 2,44 t ha ${ }^{-1}$. Sa prinosom od 21,40 t ha poslednje mesto zauzima najređi usev (20.408 biljaka ha ${ }^{-1}$ ). Vidi se da gustina useva za ispitivani kupus (srpski melez 4) treba da iznosi oko 35.000 biljaka ha $^{-1}$.

\section{References}

1. AVAKIMOV L.G. (1988): Sortovie osobenosti formirovania urozaja pozdnespeloj belokocanoj kapusti. Selekcija, semenovodstvo i sortovaja tehnologija proizvodstva ovoscej, Kolos, Moskva, 137-143.

2. BRADSHAW J.E. (1984): The effect of sowing date, plant spacing and nitrogen top-dressing on the dry matter yield and concentration of cabbage cultivars (Brassica oleracea var. capitata L.) grown for fodder. Crop Research, 24 (2), 97-104.

3. GHANTI P., SOUNDA G., JANA P.K., SOM M.G. (1982): Effect of levels of nitrogen, phosphorus and spacing on yield characters of cabbage. Vegetable Science, 9 (1), 1-4.

4. KANG C.K., OH E.J., YOON P.S., LEE D.W. (1988): The effect of nitrogen, potassium level, and planting density on the growth and productivity of cabbage (Brassica oleracea var. capitata L) in summer. Journal of the Korean Society for Horticultural Science, 29 (1), 1-8.

5. MAKAREVIC A.J. (1998): Kapusta. Biblioteka sadovoda i ogorodnika, Slovo, Minsk, 41-53.

6. MCLAURIN W.J., GRANBERRY D.M., CHANCE W.O. (1991): Leafy greens and cabbage production. Bulletin-Cooperative extension service, University of Georgia, 1067, 39-46.

7. RAHMAN A., HAQUE A. (1982): Effect of plant density on the growth and yield of cabbage. Bangladesh Journal of Agriculture, 7 (3/4), 9-14.

8. SRINIVAS K. (1982): Growth and yield of cabbage as affected by spacing and fertilizers. Singapure Journal of primary industries, $10(1), 58-63$.

9. STOFFELA P.J., FLEMING M.F. (1990): Plant population influences yield variability of cabbage. Journal of the American Society of Horticultural Science, 115 (5), 708-711.

10. SZALVA P. (1982): Kaposztafelek. Mezogazdasagi Kiado, Budapest, 193-207. 